\title{
Cold Acclimation Responses of Three Cool-season Turfgrasses and the Role of Proline-associated Pentose Phosphate Pathway
}

\author{
Dipayan Sarkar and Prasanta C. Bhowmik ${ }^{1}$ \\ Department of Plant, Soil, and Insect Sciences, Stockbridge Hall, University of Massachusetts, \\ Amherst, MA 01003 \\ Young-In-Kwon and Kalidas Shetty \\ Department of Food Sciences, Chenoweth Laboratory, University of Massachusetts, Amherst, MA \\ 01003
}

\begin{abstract}
AdDitional INDEX wORDs. catalase, glucose-6-phosphate dehydrogenase, guaiacol peroxidase, phenolic, succinate dehydrogenase, superoxide dismutase

Abstract. The role of the antioxidant response system in association with the proline-associated pentose phosphate pathway for cold adaptation was investigated in three cool-season turfgrasses during a cold acclimation period. As phenolic biosynthesis and antioxidant stimulation is proposed to be linked to the proline-associated pentose phosphate pathway, this study was aimed to determine the active role of proline in metabolic regulation and its relationship with the cold stress tolerance mechanism of cool-season turfgrasses. In this study, significant accumulation of total soluble phenolics and higher total antioxidant activity was observed in creeping bentgrass (Agrostis stolonifera L.), kentucky bluegrass (Poa pratensis L.), and perennial ryegrass (Lolium perenne L.) during cold acclimation, confirming the direct and indirect role of phenolics to counter low temperature-induced oxidative stress. A positive correlation between high phenolic content and the proline-associated pentose phosphate pathway was also found in investigated turfgrass species during a cold acclimation period. Low succinate dehydrogenase activity along with the high glucose6-phosphate dehydrogenase activity in cold-acclimated turfgrass species suggested a probable shift of carbon flux from the energy-consuming tricarboxylic cycle to the alternative energy-efficient proline-associated pentose phosphate pathway to induce a better cold stress tolerance mechanism in these cool-season turfgrasses. Higher proline accumulation in cold-acclimated turfgrass species also supported the above findings and a probable proline oxidation to support mitochondrial oxidative phosphorylation was observed in acclimated kentucky bluegrass based on the activity of proline dehydrogenase, which likely supports the active metabolic role of proline in stress-induced situations. Through this study, a significant variation in cold stress tolerance mechanisms was observed among three investigated cool-season turfgrass species during cold acclimation. Furthermore, a high cold stress tolerance characteristic was observed in kentucky bluegrass by adapting a more efficient pathway for an antioxidant response linked to proline accumulation.
\end{abstract}

Turfgrasses growing under cool humid, cool subhumid, and cool semiarid climates are known as cool-season turfgrass. Cool-season turfgrasses have originated and adapted predominately in cooler regions of the world (Beard, 1973). Thus, all cool-season grasses exhibit above-average low-temperature hardiness, although it varies between species and cultivars. The majority of cool-season turfgrass species have cold hardiness characteristics, but few cool-season turfgrasses are susceptible to cold injury just below freezing. Among coolseason grasses, perennial ryegrass, tall fescue (Festuca arundianacea Schreb.), and annual bluegrass (Poa апnиa L.) are most susceptible to low temperature injury, while creeping bentgrass and kentucky bluegrass are the most tolerant species.

Cold hardening or acclimation is a complex developmental process through a nonheritable modification of structures and functions as a response to cold, which minimizes cold injuries and improves the fitness of an individual plant (Alberdi and Corcuera, 1991). During the cold acclimation period, there is a modulation of many biochemical and physiological events that

Received for publication 3 Dec. 2008. Accepted for publication 8 Mar. 2009. ${ }^{1}$ Corresponding author. E-mail: pbhowmik@pssci.umass.edu. are required to achieve maximum cold hardiness (Steponkus, 1990). The first stage of cold acclimation is initiated after the cessation of plant growth during fall season. The changes in photoperiod (short day) and lowering temperatures $\left(10-20{ }^{\circ} \mathrm{C}\right)$ induce the acclimation process in the majority of plants (Sakai and Larcher, 1987). Cool-season turfgrass requires temperatures between 0 and $8{ }^{\circ} \mathrm{C}$ for a 2- to 3-week period to initiate the cold-hardening process (Beard, 1973). The second stage of cold acclimation is induced by low temperatures below the subzero level.

The potential role of antioxidant enzymes in protecting plants from cold injury is well established (Christie et al., 1994; Polle, 1997; Rice-Evans et al., 1997). During high illumination, if low temperatures limit the utilization of reductants produced in photosynthesis, then they enhance photooxidative stress. With decreasing temperatures, the solubility of air increases, which leads to a higher concentration of oxygen and thus enhances the risk of oxidative stress at low temperatures (Polle, 1997). Plant injury caused by freezing stress, along with illumination, may be mediated by reactive oxygen species such as superoxide radicals, singlet oxygen, hydrogen peroxide, and hydroxyl radicals (Wise and Naylor, 1987). Higher concentrations of $\mathrm{O}_{2}^{-}$were reported from lethally frozen 
crown of winter wheat (Triticum aestivum L.) compared with unstressed or sublethally stressed wheat plants (Kendall and McKersie, 1989). Antioxidant response systems are able to maintain a cellular homeostasis that governs stress tolerance mechanisms in plants at low temperatures. In field conditions, the cold acclimation process generally invokes important changes in plant physiology, including increases in antioxidative protection (Pinhero et al., 1997). Antioxidant enzymes not only scavenge free radicals, but also induce important signals to protect plants from low temperature stress (Polle, 1997).

The role of phenolic antioxidants in plant abiotic stress response and protection has received less attention until now. Studies on the free radical scavenging properties of flavonoids have opened the characterization of other phenolic compounds as antioxidants. The structural chemistry of polyphenols suggests their free radical scavenging properties (Rice-Evans et al., 1997). The antioxidant activity of phenolics is actually governed by their redox properties, which play a crucial role in adsorbing and neutralizing free radicals, quenching single and triplet oxygen, or decomposing peroxides (Rice-Evans et al., 1997; Shetty, 2004). Few studies have indicated increases in phenolic acids relative to low temperature stress (Prasad, 1996; Rice-Evans et al., 1997). Pennycooke et al. (2005) found cold acclimation induced the accumulation of total phenolics, which had positive correlation to antioxidant capacity in petunia (Petunia L.). The recovery from the chilling stress indicates some kind of antioxidant protection, including the stimulation of anthocyanin and phenylpropanoid biosynthesis (Christie et al., 1994).

The induction of the phenylpropanoid pathway and the production of proline in plants during abiotic stress is well documented (Christie et al., 1994; Dorffling et al., 1997). Studies in wheat indicated higher accumulation of proline during acclimation and its association in improvement of frost tolerance (Dorffling et al., 1997). Proline is synthesized from glutamate by a series of reduction reactions. In this synthesis process, proline and pyrroline-5-carboxylate (P5C) may regulate redox and hydride ion-mediated stimulation of the pentose phosphate pathway (Hagedorn and Phang, 1983; Phang, 1985). During respiration, oxidation reactions produce hydride ions, which help reduction of P5C to proline into the cytosol. Within mitochondria, instead of nicotinamide adenine dinucleotide dehydrogenase (NADH), proline acts as a reducing equivalent and can support oxidative phosphorylation. The reduction of $\mathrm{P} 5 \mathrm{C}$ in the cytosol provides nicotinamide adenine dinucleotide phosphate (NADP+), which is a cofactor for glucose-6-phosphate dehydrogenase (G6PDH). G6PDH plays crucial role by catalyzing the first rate-limiting step of the pentose phosphate pathway.

Phang (1985) first proposed this model, and stated the role of proline-associated pentose phosphate pathway in the stimulation of purine metabolism via ribose-5-phosphate in animal cells. On the basis of this above-mentioned concept, Shetty (1997) proposed a model that the proline-mediated pentose phosphate pathway could stimulate the shikimate and phenylpropanoid pathways in plants, and therefore, the modulation of this pathway could lead to the stimulation of phenolic phytochemicals. This model has also been proposed for the mode of action of phenolic metabolites in the stimulation of the endogenous antioxidant response based on the correlation between stress-stimulated phenolic biosynthesis and stimula- tion of the antioxidant enzyme response pathways in plants. Proline and G6PDH correlation during the phenolic response was also associated with phenolic content and potential polymerization of phenolics by guaiacol peroxidase (GPX). Antioxidant properties of phenolics based on free radical scavenging activity of phenolics and its enzymatic quenching linked to superoxide dismutase (SOD) and catalase (CAT) (Bowler et al., 1994; McCue et al., 2000; McCue and Shetty, 2002; Shetty and Wahlqvist, 2004). Because NADH production would be reduced as carbon flux is diverted to proline via $\alpha$ ketogluterate and glutamic acid, proline could be used as an alternative-reducing equivalent instead of NADH to drive mitochondrial oxidative phosphorylation for energy (adenosine triphosphate-ATP) synthesis (Shetty, 2004; Shetty and Wahlqvist, 2004). The synthesis of phenolic metabolites and stimulation of the antioxidant response pathway would be able to minimize the oxidation-induced damage within tissues where it occurs. This study is based on the rationale that the proline-associated pentose phosphate pathway may play a crucial role under low temperature stress in turfgrass and as a result, phenolic phytochemicals can effectively counter oxidative stress within the cell during winter through phenolic biosynthesis and stimulation of the antioxidant enzyme response.

Among cool-season turfgrasses, many species (perennial ryegrass, annual bluegrass, and tall fescue) are susceptible to low temperature injury, while others are tolerant species (creeping bentgrass and kentucky bluegrass). Limited studies have been carried out to understand the physiological and biochemical mechanisms of cool-season turfgrass during acclimation and their role in cold tolerance (Bhowmik et al., 2008). As research conducted in other plants found an association between high phenolic content and higher antioxidant enzymes with better cold tolerance (Javanmardi et al., 2003; Pennycooke et al., 2005), we hypothesized that this cellular mechanism is also similar in cool-season turfgrasses under cold stress. The present study was initiated to evaluate the cold acclimation behavior of cool-season turfgrass, and to understand the function of the antioxidant response system coupled with the proline-associated pentose phosphate pathway to determine relevance to fitness during cold stress period.

\section{Materials and Methods}

Plant material and growth Conditions. Creeping bentgrass ('Penncross'), perennial ryegrass ('Palmer II'), and kentucky bluegrass ('Baron') plugs (2.5 cm diameter) were collected from the Joseph Troll Turf Research facility of University of Massachusetts, South Deerfield. All plugs were potted (4.5-cm-diameter and 6-cm-tall pots) with soil-sand mixture. All plants were initially grown in a growth chamber at a controlled temperature $\left(25 / 20^{\circ} \mathrm{C}\right.$ day/night) with a $12-\mathrm{h}$ photoperiod under fluorescent white light $\left(280 \mu \mathrm{mol} \cdot \mathrm{m}^{-2} \cdot \mathrm{s}^{-1}\right)$. Plants were fertilized and mowed once per week. All plants were grown in the above-mentioned conditions for at least 1 month. After that, five plants of each turfgrass species were transferred to another growth chamber for cold acclimation treatment $\left(20 / 10^{\circ} \mathrm{C}\right.$ day/night) for 1 week, and then $\left(15 / 8{ }^{\circ} \mathrm{C}\right.$ day/night) for 1 week more, and then $\left(4{ }^{\circ} \mathrm{C}\right.$ day/night) for 2 weeks. For the first 2 weeks, plants were grown with a 12-h photoperiod, and for the last 2 weeks, the photoperiod was reduced to $10 \mathrm{~h}$ to mimic the fall season photoperiod. Another 
five plants for each turfgrass were kept in $25 / 20{ }^{\circ} \mathrm{C}$ day/night and 12-h photoperiod conditions as a control treatment.

Enzyme EXtraction. Turfgrass leaf tissue $(200 \mathrm{mg})$ was collected at the end of each week of cold acclimation treatment and was thoroughly macerated by using a cold pestle and mortar with cold enzyme extraction buffer $[0.5 \%$ polyvinylpyrrolidone (PVP), $3 \mathrm{~mm}$ ethylenediaminetetraacetic acid (EDTA), and $0.1 \mathrm{M}$ potassium phosphate buffer, $\mathrm{pH}$ 7.5]. The extracted sample was centrifuged at $10,188 g_{\mathrm{n}}$ for $10 \mathrm{~min}$ at 2 to $5^{\circ} \mathrm{C}$ and was stored in ice. Supernatant was used for further chemical analysis.

G6PDH ASSAY. A modified method originally described by Deutsch (1983) was used. The enzyme reaction mixture containing 5.88 $\mu \mathrm{mol} \beta$-NADP, $88.5 \mu \mathrm{mol}$ magnesium chloride $\left(\mathrm{MgCl}_{2}\right), 53.7 \mu \mathrm{mol}$ glucose-6-phosphate, and $0.77 \mathrm{mmol}$ maleimide was prepared. This mixture was used to obtain baseline (zero) of the spectrophotometer reading at $340 \mathrm{~nm}$ wavelength. To $1 \mathrm{~mL}$ of this mixture, $100 \mu \mathrm{L}$ of the extracted enzyme sample was added. The rate of change in absorbance per minute was used to quantify the enzyme activity in the mixture with the help of the extinction coefficient of NADPH $\left(6.22 \mathrm{~mm}^{-1} \cdot \mathrm{cm}^{-1}\right)$ and was expressed as micromoles per milligram of protein.

Proline dehydrogenase (PDH) assay. A modified method described by Costilow and Cooper (1978) was carried out to assay the activity of $\mathrm{PDH}$. The enzyme reaction mixture containing $100 \mathrm{~mm}$ sodium carbonate buffer ( $\mathrm{pH} 10.3), 20$ $\mathrm{mm}$ L-proline solution, and $10 \mathrm{~mm}$ nicotinamide adenine dinucleotide (NAD) was used. To $1 \mathrm{~mL}$ of this reaction mixture, $200 \mu \mathrm{L}$ of extracted enzyme sample was added. The increase in absorbance was measured at $340 \mathrm{~nm}$ for $3 \mathrm{~min}$, at $32{ }^{\circ} \mathrm{C}$. The absorbance was recorded at zero time and then after $3 \mathrm{~min}$. In this spectrophotometric assay, one unit of enzyme activity is equal to the amount causing an increase in absorbance of 0.01 per min at $340 \mathrm{~nm}$ (1.0 cm light path).

SuCCINATE DEHYdRogenase (SDH) ASSAY. To assay the activity of SDH, a modified method of Bregman (1987) was used. Turfgrass tissue extract suspension was diluted with 2.0 $\mathrm{mL}$ of enzyme extraction buffer. The enzyme sample was then assayed at room temperature for SDH activity. The assay mixture containing $1.0 \mathrm{~mL}$ of $0.4 \mathrm{M}$ potassium phosphate buffer ( $\mathrm{pH} 7.2$ ), $40 \mu \mathrm{L}$ of $0.15 \mathrm{M}$ sodium succinate ( $\mathrm{pH} 7.0$ ), 40 $\mu \mathrm{L}$ of $0.2 \mathrm{M}$ sodium azide, and $10 \mu \mathrm{L}$ of $6.0 \mathrm{mg} \cdot \mathrm{mL}^{-1} 2,6-$ dichlorophenolindophenol (DCPIP) was prepared. This mixture was used to obtain baseline (zero) of the spectrophotometer reading at $600 \mathrm{~nm}$ wavelength. To $1.0 \mathrm{~mL}$ of this mixture, 200 $\mu \mathrm{L}$ of the enzyme sample was added. The rate of change of absorbance per minute was used to quantify the enzyme in the mixture using the extinction coefficient of DCPIP (19.1 $\left.\mathrm{mM}^{-1} \cdot \mathrm{cm}^{-1}\right)$.

GPX ASSAY. The activity of GPX was assayed by a modified method (Laloue et al., 1997). The enzyme reaction mixture containing $0.1 \mathrm{M}$ potassium phosphate buffer ( $\mathrm{pH} 6.8), 56 \mathrm{~mm}$ guaiacol solution, and $50 \mathrm{~mm} \mathrm{H}_{2} \mathrm{O}_{2}$ was used. To $990 \mu \mathrm{L}$ of this reaction mixture, $10 \mu \mathrm{L}$ of enzyme sample was added. The absorbance was recorded at zero time and then after $5 \mathrm{~min}$. The rate of change in absorbance per minute was used to quantify the enzyme in the mixture by using the extinction coefficient of the oxidized product tetraguaiacol (26.6 $\mathrm{mM}^{-1} \cdot \mathrm{cm}^{-1}$ ).

CAT ASSAY. The CAT activity was assayed according to the methods of Beers and Sizer (1952). To $1.9 \mathrm{~mL}$ of distilled water, $1 \mathrm{~mL}$ of $0.059 \mathrm{M}$ hydrogen peroxide (Merck's Superoxol or equivalent grade; Merck, Whitehouse Station, NJ) in $0.05 \mathrm{M}$ potassium phosphate $(\mathrm{pH}$ 7.0) was added. This mixture was incubated in a spectrophotometer for 4 to $5 \mathrm{~min}$ to achieve temperature equilibration and to establish blank rate. To this mixture, $0.1 \mathrm{~mL}$ of diluted enzyme sample was added and the disappearance of peroxide was followed spectrophotometrically by recording the decrease in absorbance at $240 \mathrm{~nm}$ for 2 to $3 \mathrm{~min}$. The change in absorbance $\Delta \mathrm{A}_{240} / \mathrm{min}$ from the initial (45 s) linear portion of the curve was calculated. One unit of CAT activity was defined as amount that decomposes $1 \mu \mathrm{mol}$ of $\mathrm{H}_{2} \mathrm{O}_{2}$ :

Units $/ \mathrm{mg}=$
$\frac{\left(\Delta A_{240} / \mathrm{min}\right) \times 1000}{43.6 \times \text { milligrams enzyme per millimeter reaction mixture }}$

SOD ASSAY. A competitive inhibition assay was performed that used xanthine-xanthine oxidase-generated superoxide to reduce nitroblue tetrazolium (NBT) to blue formazan. Spectrophotometric assay of SOD activity was carried out by monitoring the reduction of NBT at $560 \mathrm{~nm}$ (Oberley and Spitz, 1984). The reaction mixture contained $13.8 \mathrm{~mL}$ of $50 \mathrm{~mm}$ potassium phosphate buffer ( $\mathrm{pH} 7.8$ ) containing $1.33 \mathrm{~mm}$ diethylenetetraaminepentaacetic acid (DETAPAC); $0.5 \mathrm{~mL}$ of $2.45 \mathrm{~mm}$ NBT, $1.7 \mathrm{~mL}$ of $1.8 \mathrm{~mm}$ xanthine, and $40 \mathrm{IU} / \mathrm{mL}$ catalase. To $0.8 \mathrm{~mL}$ of reagent mixture, $100 \mu \mathrm{L}$ of phosphate buffer and $100 \mu \mathrm{L}$ of xanthine oxidase was added. The change in absorbance at $560 \mathrm{~nm}$ was measured every $20 \mathrm{~s}$ for $2 \mathrm{~min}$ and the concentration of xanthine oxidase was adjusted to obtain a linear curve with a slope of 0.025 absorbance per min. The phosphate buffer was then replaced by the enzyme sample and the change in absorbance was monitored every $20 \mathrm{~s}$ for $2 \mathrm{~min}$. One unit of SOD was defined as the amount of protein that inhibits NBT reduction to $50 \%$ of the maximum.

TOTAL PROTEIN ASSAY. Protein content was determined by the method of Bradford assay (Bradford 1976). One part of dye reagent (Protein Assay Kit II; Bio-Rad Laboratory, Hercules, CA) was diluted with four parts of distilled water. A volume of $5 \mathrm{~mL}$ of diluted dye reagent was added to $50 \mu \mathrm{L}$ of the turfgrass tissue extract. After vortexing and incubating for $5 \mathrm{~min}$, the absorbance was measured at $595 \mathrm{~nm}$ against a blank ( $5 \mathrm{~mL}$ of reagent and $50 \mu \mathrm{L}$ of buffer solution) by using a ultraviolet-VIS spectrophotometer (Genesys; Milton Roy, Rochester, NY).

ABTS [2,2' -AZINO-BIS(3-ETHYLBENZTHIAZOLINE-6-SULPHONIC ACID)] CATION RADICAL AND ANTIOXIDANT ACTIVITY ASSAY. The total antioxidant activity of turfgrass leaf extract was measured by the $\mathrm{ABTS}^{+}$radical cation-decolorization assay involving preformed $\mathrm{ABTS}^{+}$radical cation (Pellegrini et al., 1999). ABTS (Sigma, St. Louis) was dissolved in water to a $7 \mathrm{~mm}$ concentration. $\mathrm{ABTS}^{+}$radical cation was prepared by reacting $5 \mathrm{~mL}$ of $7 \mathrm{~mm}$ ABTS stock solution with $88 \mu \mathrm{L}$ of $140 \mathrm{~mm}$ potassium persulphate, and the mixture was allowed to stand in the dark at room temperature for 12 to $16 \mathrm{~h}$ before use. Before assay, $\mathrm{ABTS}^{+}$stock solution was diluted with $95 \%$ ethanol (ratio 1:88) to give an absorbance at $734 \mathrm{~nm}$ of $0.70 \pm 0.02$, and was equilibrated to $30{ }^{\circ} \mathrm{C}$. One milliliter ABTS was added to glass test tubes containing $50 \mu \mathrm{L}$ of each tissue extract, and was mixed by a vortex mixer for $30 \mathrm{~s}$. After a 2.5 -min incubation, 
mixtures were read at $734 \mathrm{~nm}$. The readings were compared with controls, which contained $50 \mu \mathrm{L}$ of $95 \%$ ethanol instead of the extract. The Trolox reference standard for relative antioxidant activities was prepared with $5 \mathrm{~mm}$ stock solution of Trolox in ethanol for introduction into the assay system at concentrations within the activity range of the assay $(0-20 \mu \mathrm{M}$ final concentration) for preparing a standard curve to which all data were referenced. The percentage of inhibition was calculated by:

$$
\% \text { inhibition }=\frac{\left(\left[\mathrm{A}_{734}{ }^{\text {control }}-\mathrm{A}_{734}{ }^{\text {extract }}\right]\right.}{\left.\left[\mathrm{A}_{734}{ }^{\text {control }}\right]\right)} \times 100
$$

Total soluble PHenolic ASSAY. The total soluble phenolics were determined by an assay modified from Shetty et al. (1995). A quantity of $50 \mathrm{mg}$ of fresh weight (FW) turfgrass leaf tissue was immersed in $2.5 \mathrm{~mL}$ of $95 \%$ ethanol and was kept in the freezer for $48 \mathrm{~h}$. After $48 \mathrm{~h}$, the sample was homogenized and centrifuged at $12,225 g_{\mathrm{n}}$ for $10 \mathrm{~min}$. Then, $0.5 \mathrm{~mL}$ of sample supernatant was diluted with $0.5 \mathrm{~mL}$ of distilled water and was transferred into a test tube with $1 \mathrm{~mL}$ of $95 \%$ ethanol and $5 \mathrm{~mL}$ of distilled water. In each sample, $0.5 \mathrm{~mL}$ of $50 \%$ (v/v) FolinCiocalteu reagent (Sigma) was added and mixed. After 5 min, 1 $\mathrm{mL}$ of $5 \% \mathrm{Na}_{2} \mathrm{CO}_{3}$ was added to the reaction mixture and was allowed to stand for $60 \mathrm{~min}$. A blank was prepared with $0.5 \mathrm{~mL}$ of distilled water instead of sample. Absorbance was noted at $725 \mathrm{~nm}$ after $1 \mathrm{~h}$. The absorbance values were converted to total phenolics and were expressed in milligram equivalents of gallic acid per gram of FW of the sample. Standard curves were established using various concentrations of gallic acid in $95 \%$ ethanol.

High-PERFORMANCE LIQUID CHROMATOGRAPHY (HPLC) ANALYSIS OF PROLINE. HPLC analysis was performed using an liquid chromatograph (model 1100; Agilent Technologies, Santa Clara, CA) equipped with a diode array detector (DAD 1100; Agilent Technologies). The analytical column was reverse phase Nucleosil C18 $(250 \mathrm{~nm} \times 4.6 \mathrm{~mm}$ with a packing material of $5 \mu \mathrm{m}$ particle size; Agilent Technologies). The extract samples were eluted out in an isocratic manner with a mobile phase consisting of $20 \mathrm{~mm}$ potassium phosphate $(\mathrm{pH} 2.5$ by phosphoric acid) at a flow rate of $1 \mathrm{~mL} / \mathrm{min}$ and were detected at $210 \mathrm{~nm}$. L-Proline (Sigma) dissolved in the $20 \mathrm{~mm}$ potassium phosphate solution was used to calibrate the standard curve. The amount of proline in the sample was reported as milligrams of proline per gram of FW.

Photochemical Efficiency. Photochemical efficiency of turfgrass shoots was measured by using a fluorometer (OS1-FL; Opti-Sciences, Tyngsboro, MA). The test was carried in darkadapted mode and $\mathrm{F}_{\mathrm{v}} / \mathrm{F}_{\mathrm{m}}\left[\mathrm{F}_{\mathrm{v}} / \mathrm{F}_{\mathrm{m}}=\left(\mathrm{F}_{\mathrm{m}}-\mathrm{F}_{\mathrm{o}}\right) / \mathrm{F}_{\mathrm{m}}\right.$ the ratio of variable fluorescence to maximal fluorescence] ratio was calculated. Plants were kept in dark at least $2 \mathrm{~h}$ before the measurement.

Statistical analysis. Experiments were carried out in completely randomized design with four replications. The effect of cold acclimation on turfgrasses was determined by the analysis of variance (ANOVA) of SAS (version 8.2; SAS Institute, Cary, NC). Differences among acclimated and nonacclimated turfgrass species at the end of each week of cold acclimation treatment were determined by the least significant difference (LSD) test at the $0.05 P$ level.

\section{Results}

Changes in total soluble Phenolics and FREe RAdicalLINKED ANTIOXIDANT ACTIVITY OF COOL-SEASON TURFGRASSES DURING ACCLImation. Stimulation of phenolic biosynthesis was observed during the cold acclimation period in all three turfgrass species. Higher total soluble phenolic content was found after a constant $4{ }^{\circ} \mathrm{C}$ day/night temperature for 2 weeks with a 10 -h photoperiod (Fig. 1A). The highest phenolic content was observed in acclimated creeping bentgrass, followed by kentucky bluegrass and perennial ryegrass. After initial reduction of temperature $\left(20 / 10{ }^{\circ} \mathrm{C}\right.$ day/night for 1 week), total phenolic content of acclimated perennial ryegrass was lower when compared with control. However, with further reduction in temperature to $4{ }^{\circ} \mathrm{C}$ day/night, acclimated perennial ryegrass plants had higher phenolic content. In general, higher phenolic content was found in kentucky bluegrass plants, and along with cold acclimation, further phenolic stimulation was observed. Similarly, total antioxidant activity (ABTS assay) also increased in all three turfgrass species with gradual reduction of temperature and photoperiod (Fig. 1B). After the first 2 weeks of acclimation at higher temperatures $\left(20\right.$ and $\left.15^{\circ} \mathrm{C}\right)$, total antioxidant activity of perennial ryegrass did not change when compared with the control. However, further reduction of temperature to a $4{ }^{\circ} \mathrm{C}$ constant temperature with a $10-\mathrm{h}$ photoperiod for the first and second week caused a significant stimulation of antioxidant activity in perennial ryegrass. The highest total antioxidant activity was observed in acclimated kentucky bluegrass followed by acclimated creeping bentgrass and acclimated perennial ryegrass plants. In acclimated creeping bentgrass plants, total antioxidant activity was significantly higher when compared with control at all stages, except at 20/ $10^{\circ} \mathrm{C}$ day/night temperature.

G6PDH AND SDH ACTIVITY DURING COLD ACCLIMATION. Results indicated that G6PDH activity was significantly higher in all acclimated turfgrass plants compared with the control (Fig. 2A). In kentucky bluegrass and perennial ryegrass, initial reduction of temperature for week $1\left(20 / 10{ }^{\circ} \mathrm{C}\right.$ day/night $)$ significantly increased activity of this crucial enzyme compared with control $\left(25 / 20{ }^{\circ} \mathrm{C}\right.$ day/night). Further the activity of G6PDH in kentucky bluegrass similarly increased when compared with control after the reduction to a $4{ }^{\circ} \mathrm{C}$ constant temperature with a 10 -h photoperiod. The extent of G6PDH activity was higher in acclimated perennial ryegrass compared with kentucky bluegrass at all lower temperatures. Creeping bentgrass initially had reduced G6PDH activity at $20 / 10{ }^{\circ} \mathrm{C}$ day/night, which gradually was stimulated at a lower acclimation temperature. The extent of stimulation was much lower than well-acclimatizing perennial ryegrass and kentucky bluegrass. SDH activity of all acclimated turfgrass plants was reduced significantly when compared with control $\left(25 / 20{ }^{\circ} \mathrm{C}\right.$ day/night) with a reduction of temperature (Fig. 2B). Reduction of SDH activity was more prominent in kentucky bluegrass, as this species also showed the highest basal SDH activity in nonacclimated conditions. The lowest SDH activity was observed in acclimated perennial ryegrass plants.

Changes in PRoline Content and PDH aCtivity. This study revealed that the total proline content of acclimated turfgrass species was significantly higher when compared with the control $\left(25 / 20{ }^{\circ} \mathrm{C}\right.$ day/night $)$. With the initial reduction of temperature $\left(20 / 10{ }^{\circ} \mathrm{C}\right.$ day/night), proline content increased significantly in all three investigated turfgrass plants, and it 

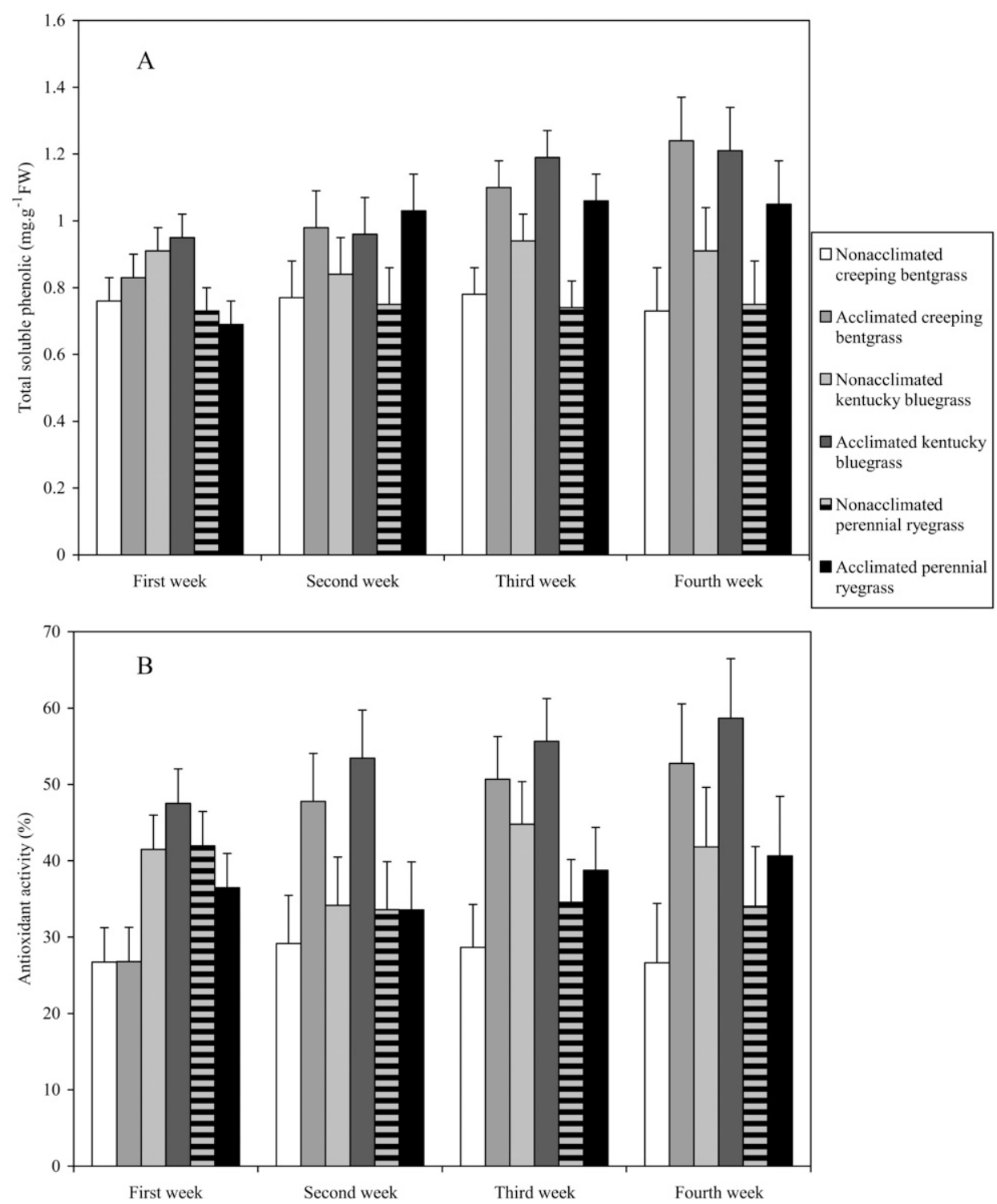

Fig. 1. Total soluble phenolic (A) and antioxidant activity (B) of creeping bentgrass, kentucky bluegrass, and perennial ryegrass during cold acclimation treatments (first week $=20 / 10^{\circ} \mathrm{C}$ day/night with 12 -h photoperiod, second week $=15 / 8{ }^{\circ} \mathrm{C}$ day/night with 12 -h photoperiod, third week $=4{ }^{\circ} \mathrm{C}$ day/night with 10 -h photoperiod, fourth week $=4{ }^{\circ} \mathrm{C}$ day/night with 10 -h photoperiod). Vertical bars are LSD values $(P \leq 0.05)$ for acclimated and nonacclimated species comparisons at end of each week of cold acclimation treatment.

with high proline content, reflecting lower oxidation and poor acclimation tolerance.

Changes in SOD, CAT, AND GPX ACTIVity. To understand whether cold acclimation was able to modulate antioxidant enzymes in cool-season turfgrass plants, the activity of three important antioxidant enzymes (SOD, CAT, and GPX) was measured. The activity of SOD was comparatively lower in acclimated turfgrass when compared with control, although after 4 weeks of cold treatment, it increased in acclimated creeping bentgrass as well as in acclimated kentucky bluegrass plants (Table 1). Overall, changes in SOD activity were not significant in these investigated turfgrass plants during acclimation. However, CAT activity changed significantly in all three turfgrass species during acclimation (Table 2). The highest CAT activity was observed in acclimated creeping bentgrass plants followed by kentucky bluegrass and perennial ryegrass at the $20 / 10{ }^{\circ} \mathrm{C}$ day/night temperature with a 12 -h photoperiod. The activity of CAT in acclimated turfgrass reduced in the middle of 2 weeks of cold treatment $\left(15 / 8{ }^{\circ} \mathrm{C}\right.$ day/night for 1 week and a $4{ }^{\circ} \mathrm{C}$ constant temperature for 1 week), but again increased after the end of an additional 1 week at a $4{ }^{\circ} \mathrm{C}$ constant temperature. GPX activity also changed significantly in all three turfgrass species during acclimation (Table 3 ). The activity of this enzyme was significantly higher in acclimated creeping bentgrass plants compared with control, and it increased gradually during acclimation at lower temperatures. Higher GPX activity in perennial ryegrass

remained in similar magnitude in creeping bentgrass, and in perennial ryegrass (Fig. 3A). Total proline content of acclimated kentucky bluegrass plants was reduced in the later phase of acclimation when compared with the initial content $\left(20 / 10{ }^{\circ} \mathrm{C}\right.$ day/night), indicating a potential utilization. To confirm proline oxidation for potential energy under stress, PDH activity was measured in cool-season turfgrass during acclimation. Initially, the PDH activity was lower in all three acclimated turfgrass plants, but in later cold-acclimated phases, activity of this enzyme significantly increased over control (Fig. 3B). Higher PDH activity was observed in acclimated kentucky bluegrass plants, which also corresponded with low proline content in same species, confirming likely proline oxidation for energy under acclimation stress. Lower PDH activity was found in creeping bentgrass, and it also correlated was observed after initial acclimation treatment $\left(20 / 10^{\circ} \mathrm{C}\right.$ day/ night). Higher GPX activity is directly proportional with high G6PDH activity and with high phenolic content, particularly in creeping bentgrass and kentucky bluegrass plants during acclimation.

Рнотоchemical efficiency. The photosynthetic activity of three cool-season turfgrass plants was measured by using the chlorophyll fluorescence technique and data are represented as $\mathrm{F}_{\mathrm{v}} / \mathrm{F}_{\mathrm{m}}$ ratio to understand the photochemical efficiency of these turfgrass species during acclimation. The ratio represents the maximum efficiency at which light absorbed by light-harvesting antennae of photosystem II (PSII) is converted to chemical energy. Reduction of the $F_{v} / F_{m}$ ratio was observed in all three turfgrass species with lowering temperatures and photoperiod (Fig. 4). The reduction was more prominent in perennial 

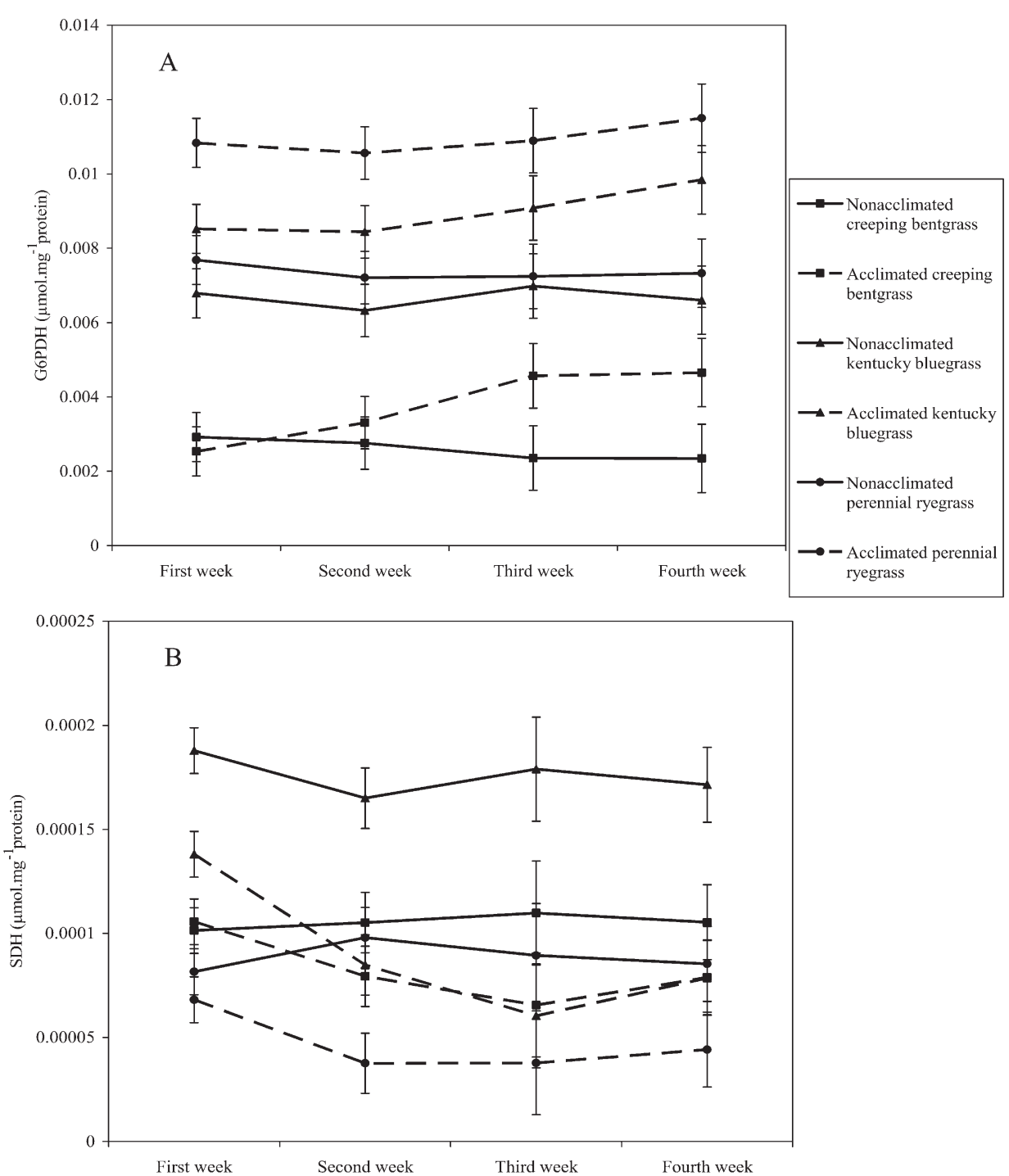

Fig. 2. Glucose-6-phosphate dehydrogenase (G6PDH) (A) and succinate dehydrogenase (SDH) (B) of creeping bentgrass, kentucky bluegrass, and perennial ryegrass during cold acclimation treatments (first week $=20 / 10^{\circ} \mathrm{C}$ day/night with 12 -h photoperiod, second week $=15 / 8{ }^{\circ} \mathrm{C}$ day/night with 12 -h photoperiod, third week $=4{ }^{\circ} \mathrm{C}$ day/night with 10-h photoperiod, fourth week $=4{ }^{\circ} \mathrm{C}$ day/night with 10 -h photoperiod). Vertical bars are LSD values $(P \leq 0.05)$ for acclimated and nonacclimated species comparisons at end of each week of cold acclimation treatment.

ryegrass, whereas acclimated kentucky bluegrass plants showed higher photochemical efficiency when compared with creeping bentgrass and perennial ryegrass.

\section{Discussion}

Environmental conditions that induce or favor photooxidative stress are common events in the growth and developmental processes of plants (Paliyath and Droillard, 1992; Polle, 1997). As a result of oxidizing capacity linked to energy metabolism, $\mathrm{O}_{2}$ acts primarily as a terminal electron acceptor in oxidative phosphorylation, which leads to the formation of a variety of reactive oxygen intermediates (Asada, 1993). The reactive oxygen species can attack cell membranes by a cascade of free radical chain reactions, resulting in extensive damage of the cell membrane and other cellular structures (Fuchs et al., 1997).
Furthermore, these intermediates can also react with the polyunsaturated fatty acids and cholesterols present in the cell membrane and can generate oxidized lipids, which can contribute to apoptosis or cell death (Halliwell and Gutteridge, 1989). Reactive oxygen species may also cause damage to DNA or can induce the rapid depletion of cellular NAD/NADH pools, leading to depletion of ATP reserves and cell death (Christ et al., 1993).

We hypothesized that to deal cold stress, a more energy-efficient antioxidant defense system could play significant role in cool-season turfgrasses through the stimulation of phenolic phytochemical production and the antioxidant response system while maintaining energy needs from proline synthesis. We also assume that in plants, this whole mechanism and adjustment takes place during acclimation in time of gradual reduction of temperature (low temperature) and photoperiod (short day).

We observed a significant accumulation of total soluble phenolics during acclimation in all three investigated cool-season turfgrass species. Higher phenolic content in creeping bentgrass and kentucky bluegrass compared with perennial ryegrass indicated the possible correlation of this metabolic pool to cold tolerance in these turfgrass species. Low phenolic content of perennial ryegrass may reflect one critical aspect of their low coldtolerant characteristic. Phenolic compounds are secondary metabolites, distributed widely in plants (Javanmardi et al., 2003). The antioxidant activity of phenolics is determined by its reduction potential, ability to stabilize and delocalize the unpaired electron, reactivity with other antioxidants, and transition metal chelating potential. Polyphenols have all the above characteristics and thus play significant role in the antioxidant defense pathways in plants. The most widely distributed phenolic components in plant tissues are the hydroxycinamic acids, p-coumaric, and caffeic and ferulic acids, which are synthesized via the shikimate pathway (Rice-Evans et al., 1997; Shetty, 2004; Shetty and Wahlqvist, 2004). Many phenylpropanoid compounds such as flavonoids, isoflavonoids, anthocyanins, and polyphenols are induced in response to cold stress in plants (Christie et al., 1994). Accumulation of soluble phenolics during acclimation in these cool-season turfgrass species suggests the probable role of phenolics as antioxidants to counter oxidative free radicals during cold stress. Phenolics can directly quench the free radicals or indirectly can stimulate the response of antioxidant 

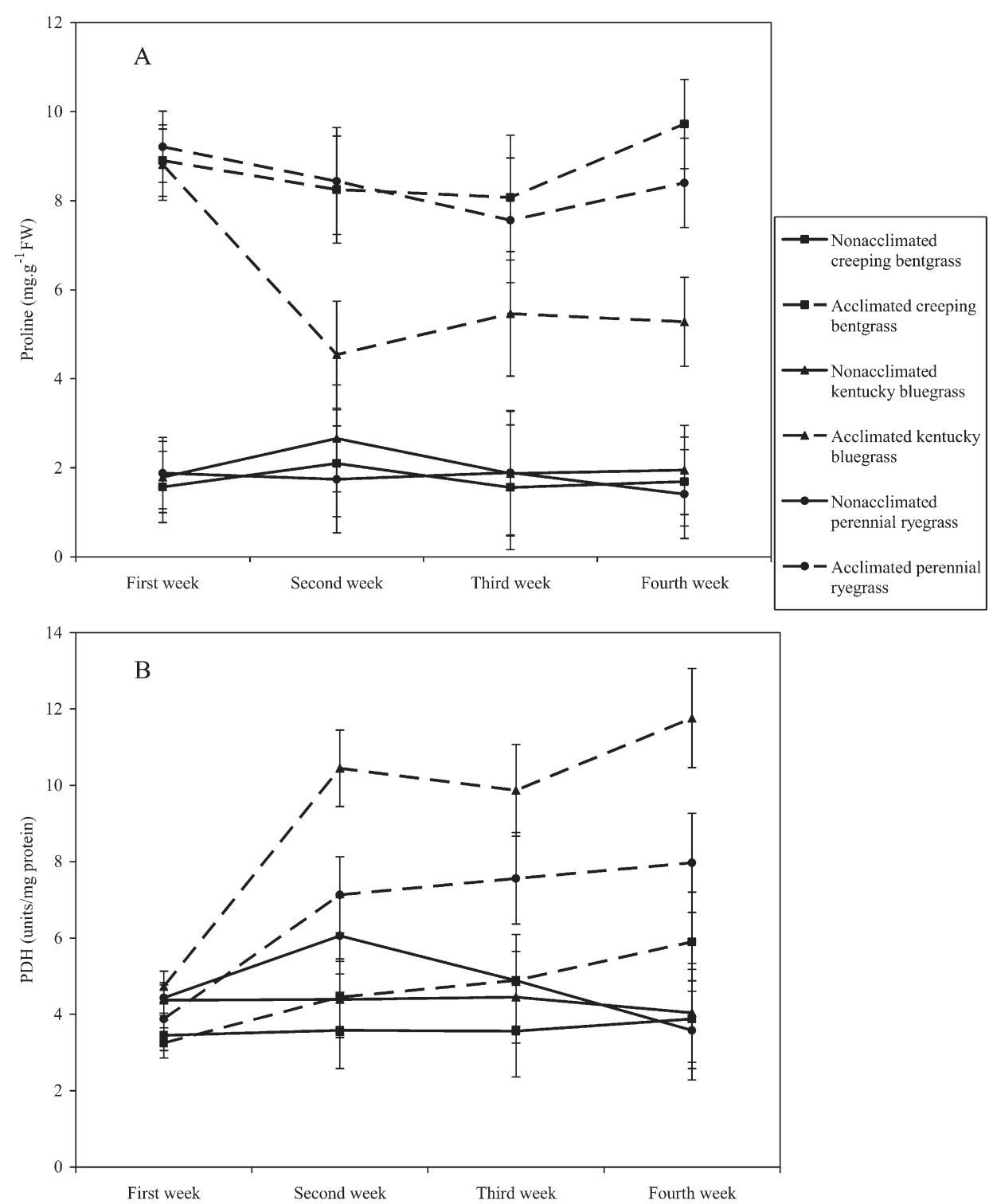

Fig. 3. Proline (A) and proline dehydrogenase (PDH) (B) of creeping bentgrass, kentucky bluegrass, and perennial ryegrass during cold acclimation treatments (first week $=20 / 10^{\circ} \mathrm{C}$ day/night with 12 -h photoperiod, second week $=15 / 8{ }^{\circ} \mathrm{C}$ day/night with 12 -h photoperiod, third week $=4{ }^{\circ} \mathrm{C}$ day/night with 10 -h photoperiod, fourth week $=4{ }^{\circ} \mathrm{C}$ day/night with 10 -h photoperiod). Vertical bars are LSD values $(P \leq 0.05)$ for acclimated and nonacclimated species comparisons at end of each week of cold acclimation treatment. enzymes such as SOD and GPX to scavenge peroxidase or other reactive oxygen free radicals during the stress period.

The results of total antioxidant activity (based on free radical scavenging-linked ABTS assay) also correlated with total phenolic content in these turfgrass species. High antioxidant activity was observed in acclimated kentucky bluegrass and in acclimated creeping bentgrass compared with perennial ryegrass. As a part of their aerobic existence, plants had to develop an effective defensive system to deal with these reactive intermediates of oxygen metabolism. Balancing reactive oxygen intermediates by antioxidants is a key function of the cell to counter oxidative challenges (Fuchs et al., 1997). The antioxidant defense system is a dynamic system and it is composed of hydrophilic and lipophilic metabolites and antioxidant enzymes (Polle, 1997). The potential role of antioxidant enzymes in protecting plants from cold injury is well known (Christie et al., 1994).

Analysis of antioxidant enzymes also showed an interesting trend in acclimated turfgrass plants. The activity of SOD in acclimated turfgrass plants was lower when compared with the control in the early acclimation phase, but it was a little higher at the end of acclimation in creeping bentgrass and kentucky bluegrass. In maize (Zea mays L.) and spinach (Spinacia oleracea L.), high SOD activity in response to high light in combination with low temperature was observed (Jahnke et al., 1991; Schöner and Krause,

Table 1. Superoxide dismutase (SOD) activity of cold-acclimated and nonacclimated creeping bentgrass, kentucky bluegrass, and perennial ryegrass during 4 weeks of cold acclimation treatments.

\begin{tabular}{|c|c|c|c|c|}
\hline \multirow[b]{2}{*}{ Treatments } & \multicolumn{4}{|c|}{ SOD (units/mg protein) } \\
\hline & First week ${ }^{z}$ & Second week ${ }^{\mathrm{z}}$ & Third week ${ }^{\mathrm{z}}$ & Fourth week ${ }^{z}$ \\
\hline Nonacclimated creeping bentgrass & $8.4 b^{y}$ & $9.78 \mathrm{~b}$ & $10.25 \mathrm{a}$ & $8.48 \mathrm{~b}$ \\
\hline Acclimated creeping bentgrass & $9.45 \mathrm{~b}$ & $8.12 \mathrm{c}$ & $8.45 \mathrm{~b}$ & $10.65 \mathrm{a}$ \\
\hline Acclimated kentucky bluegrass & $8.94 \mathrm{~b}$ & $8.49 \mathrm{bc}$ & $10.08 \mathrm{a}$ & $11.24 \mathrm{a}$ \\
\hline Nonacclimated perennial ryegrass & $8.85 \mathrm{~b}$ & $11.16 \mathrm{a}$ & $9.08 \mathrm{ab}$ & $11.16 \mathrm{a}$ \\
\hline Acclimated perennial ryegrass & $8.55 \mathrm{~b}$ & $8.5 \mathrm{bc}$ & $9.05 \mathrm{ab}$ & $10.45 \mathrm{a}$ \\
\hline
\end{tabular}

${ }^{\mathrm{z}}$ First week $=20 / 10{ }^{\circ} \mathrm{C}$ day/night with 12 -h photoperiod, second week $=15 / 8{ }^{\circ} \mathrm{C}$ day/night with 12-h photoperiod, third week $=4{ }^{\circ} \mathrm{C}$ day $/$ night with 10-h photoperiod, fourth week $=4{ }^{\circ} \mathrm{C}$ day/night with 10 -h photoperiod. Shoot samples were collected at the end of each week of cold acclimation treatment.

${ }^{y}$ Values followed by same letter within each column are not significantly different at $P=0.05$.

This test was preceded by an ANOVA, and each mean was based on four replicates. 
Table 2. Catalase (CAT) activity of cold-acclimated and nonacclimated creeping bentgrass, kentucky bluegrass, and perennial ryegrass during 4 weeks of cold acclimation treatments.

\begin{tabular}{|c|c|c|c|c|}
\hline \multirow[b]{2}{*}{ Treatments } & \multicolumn{4}{|c|}{ CAT (units/mg protein) } \\
\hline & First week ${ }^{z}$ & Second week $^{\mathrm{z}}$ & Third week ${ }^{z}$ & Fourth week \\
\hline Nonacclimated creeping bentgrass & $65.64 \mathrm{c}^{\mathrm{y}}$ & $67.89 \mathrm{c}$ & $67.86 \mathrm{~d}$ & $64.55 \mathrm{c}$ \\
\hline Acclimated creeping bentgrass & $148.51 \mathrm{a}$ & $68.96 \mathrm{c}$ & $78.96 \mathrm{c}$ & $95.48 \mathrm{~b}$ \\
\hline Nonacclimated kentucky bluegrass & $67.84 \mathrm{c}$ & $63.56 \mathrm{c}$ & $68.56 \mathrm{~d}$ & $64.72 \mathrm{c}$ \\
\hline Acclimated kentucky bluegrass & $112.34 \mathrm{~b}$ & $89.76 \mathrm{a}$ & $89.87 \mathrm{~b}$ & $105 \mathrm{a}$ \\
\hline Nonacclimated perennial ryegrass & $67.85 \mathrm{c}$ & $76.75 \mathrm{~b}$ & $67.85 \mathrm{~d}$ & $60.74 \mathrm{c}$ \\
\hline Acclimated perennial ryegrass & $107.89 \mathrm{~b}$ & $82.31 \mathrm{ab}$ & $98.76 \mathrm{a}$ & $109.27 \mathrm{a}$ \\
\hline
\end{tabular}

${ }^{\mathrm{z}}$ First week $=20 / 10{ }^{\circ} \mathrm{C}$ day/night with 12 -h photoperiod, second week $=15 / 8{ }^{\circ} \mathrm{C}$ day/night with 12 -h photoperiod, third week $=4{ }^{\circ} \mathrm{C}$ day/night with 10-h photoperiod, fourth week $=4{ }^{\circ} \mathrm{C}$ day/night with 10 -h photoperiod. Shoot samples were collected at the end of each week of cold acclimation treatment.

${ }^{y}$ Values followed by same letter within each column are not significantly different at $P=0.05$.

This test was preceded by an ANOVA, and each mean was based on four replicates.

Table 3. Guaiacol peroxidase (GPX) activity of cold-acclimated and nonacclimated creeping bentgrass, kentucky bluegrass, and perennial ryegrass during 4 weeks of cold acclimation treatments.

\begin{tabular}{|c|c|c|c|c|}
\hline \multirow[b]{2}{*}{ Treatments } & \multicolumn{4}{|c|}{ GPX $\left(\mu \mathrm{mol} \cdot \mathrm{mg}^{-1}\right.$ protein $)$} \\
\hline & First week ${ }^{\mathrm{z}}$ & Second week $^{\mathrm{z}}$ & Third week ${ }^{z}$ & Fourth week ${ }^{\mathrm{z}}$ \\
\hline Nonacclimated creeping bentgrass & $0.02 \mathrm{a}^{\mathrm{y}}$ & $0.021 \mathrm{a}$ & $0.02 \mathrm{~b}$ & $0.02 \mathrm{~b}$ \\
\hline Acclimated creeping bentgrass & $0.025 \mathrm{a}$ & $0.025 \mathrm{a}$ & $0.027 \mathrm{a}$ & $0.028 \mathrm{a}$ \\
\hline Acclimated kentucky bluegrass & $0.013 \mathrm{~b}$ & $0.009 \mathrm{c}$ & $0.015 \mathrm{bc}$ & $0.016 \mathrm{bc}$ \\
\hline Nonacclimated perennial ryegrass & $0.013 \mathrm{~b}$ & $0.012 \mathrm{bc}$ & $0.012 \mathrm{c}$ & $0.012 \mathrm{c}$ \\
\hline Acclimated perennial ryegrass & $0.02 \mathrm{a}$ & $0.015 \mathrm{~b}$ & $0.016 \mathrm{bc}$ & $0.018 \mathrm{~b}$ \\
\hline
\end{tabular}

${ }^{\mathrm{z}}$ First week $=20 / 10{ }^{\circ} \mathrm{C}$ day/night with 12 -h photoperiod, second week $=15 / 8{ }^{\circ} \mathrm{C}$ day/night with 12 -h photoperiod, third week $=4{ }^{\circ} \mathrm{C}$ day/night with 10 -h photoperiod, fourth week $=4{ }^{\circ} \mathrm{C}$ day/night with 10 -h photoperiod. Shoot samples were collected at the end of each week of cold acclimation treatment.

${ }^{y}$ Values followed by same letter within each column are not significantly different at $P=0.05$.

This test was preceded by an ANOVA, and each mean was based on four replicates.

1990). Higher SOD activity corresponded with higher protection from cold injury in alfalfa (Medicago sativa L.) (McKersie et al., 1993). Our results indicate lesser dependence of cool-season turfgrass on SOD to counter superoxide radicals during cold stress. As G6PDH activity is high in these acclimated plants, NADPH oxidase may play a role in superoxide quenching or it could be countered through a combination of other antioxidants such as phenolics, catalase, and peroxidase. Results of CAT activity confirm the above assumption, as acclimated turfgrass plants showed higher activity of this antioxidant enzyme. In chilling-sensitive plants, a significant reduction of CAT activity was observed with low temperature stress in some plants. Chilling-induced reduction in CAT activity along with increase in $\mathrm{H}_{2} \mathrm{O}_{2}$ concentration was observed in cucumber (Cucumis sativus L.) (Feierabend et al., 1992), while CAT and GPX activity increased with $\mathrm{H}_{2} \mathrm{O}_{2}$-induced acclimation in maize (Prasad et al., 1994). In our studies, GPX activity also showed a similar trend, and both antioxidant enzyme activities were higher in creeping bentgrass. As high GPX activity correlates with higher phenolic content, it indicates the possible cross linking of phenolic moieties during the biosynthesis of lignins and lignans in the plant cell wall (Morales and Barcello, 1997). High GPX activity of acclimated cool-season turfgrass suggests the role of this enzyme in defense during cold stress. Our findings indicate that catalase and GPX, along with phenolics, play a vital role to counter oxidative damage in cool-season turfgrass during cold stress period.
Higher concentrations of ascorbate and ascorbate peroxidase were also observed in evergreens in winter (Anderson et al., 1992). The importance of a balanced adjustment of electron transport and antioxidative systems for avoidance and compensation of oxidative stress was documented in maize (Massacci et al., 1995). Down-regulation of electron transport and adjustment of SOD and ascorbate peroxidase activity is crucial in the oxidative stress-tolerance mechanism (Massacci et al., 1995). Antioxidative enzymes not only scavenge free radicals, but also induce important signals to protect plants from low temperature stress. Total antioxidant activity of acclimated turfgrass reflects their cold-tolerant behavior and can give an insight into understanding the possible counter mechanisms of turfgrass species against cold stress.

The activity of G6PDH, the first rate-limiting enzyme in the pentose phosphate pathway, also increased during acclimation in all three turfgrass species. Surprisingly, perennial ryegrass showed higher G6PDH activity when compared with creeping bentgrass and kentucky bluegrass. Sagisaka (1974) reported a shift of glucose-6-phosphate metabolism from glycolysis to the pentose phosphate cycle in poplar (Populus italica L.) twigs in early autumn. With exposure to cold, increased activity of G6PDH and important changes in catalytic properties of pyruvate kinase was observed in leaves of winter rape (Brassica napus L.) (Sobczyk and Kacperska-Palacz, 1980). It seems that high availability of ATP and NADPH may be necessary for the hardening process, as it allows for synthesis of ribonucleic acid (RNA), protein phospholipids, and other substances at low 


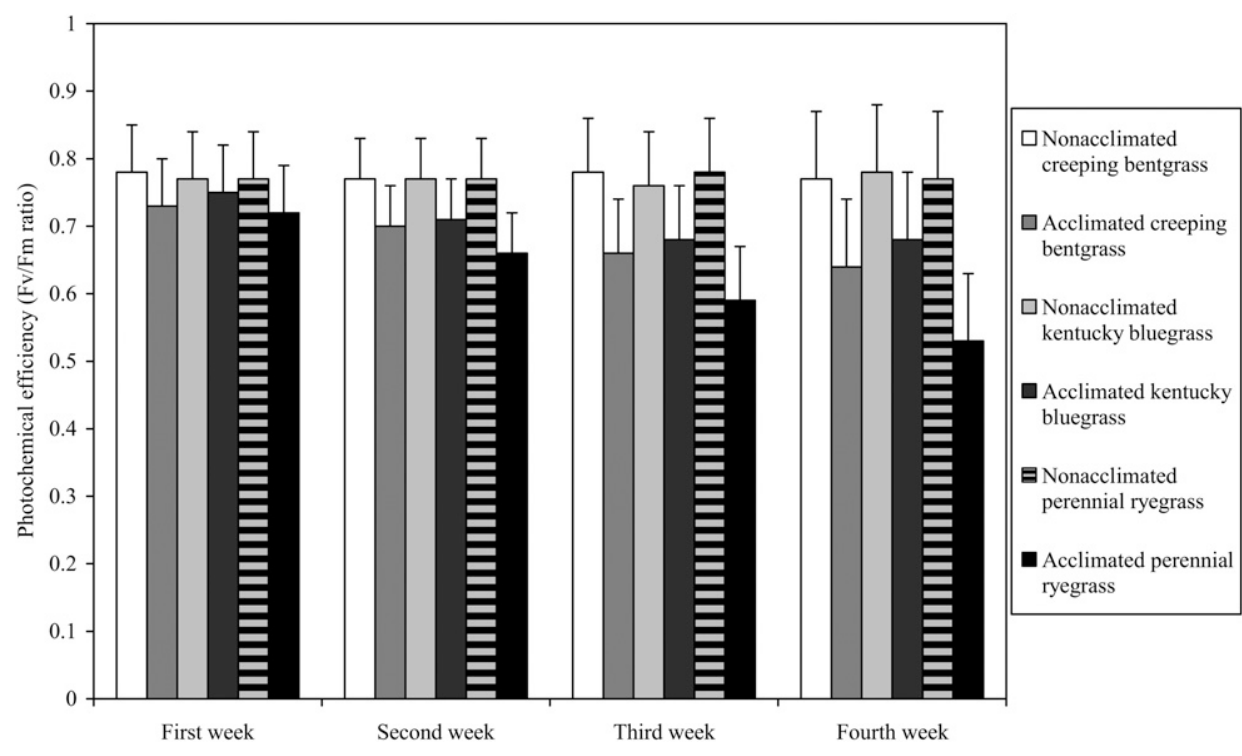

Fig. 4. Photochemical efficiency of creeping bentgrass, kentucky bluegrass, and perennial ryegrass during cold acclimation treatments (first week $=20 / 10^{\circ} \mathrm{C}$ day/night with 12 -h photoperiod, second week $=15 / 8{ }^{\circ} \mathrm{C}$ day $/$ night with 12 -h photoperiod, third week $=4{ }^{\circ} \mathrm{C}$ day/night with 10 -h photoperiod, fourth week $=4{ }^{\circ} \mathrm{C}$ day/night with 10 $\mathrm{h}$ photoperiod). Vertical bars are LsDvalues $(P \leq 0.05)$ for acclimated and nonacclimated species comparisons at end of each week of cold acclimation treatment.

temperatures. Higher activity of G6PDH with reduction of temperature and photoperiod reflects the role of the pentose phosphate pathway to support the anabolic need of these turfgrass species under cold stress. Although higher pentose phosphate pathway stimulation was observed in perennial ryegrass, it did not reflect phenolic biosynthesis and the related antioxidant response system like the other two turfgrass species studied in this investigation. Stimulation of the pentose phosphate pathway in perennial ryegrass during acclimation may divert the flux to other anabolic needs rather than meeting the needs of the shikimate or phenylpropanoid pathways. However, $\mathrm{SDH}$, the key regulatory enzyme of the tricarboxylic acid (TCA) cycle that provides NADH for mitochondrial oxidative phosphorylation, was reduced in acclimated turfgrass plants. This suggests that acclimated turfgrass species shift from the energy-consuming TCA cycle to an alternative energy-efficient system (the proline-associated pentose phosphate pathway) for preparing the plant to deal with oxidative stress during a cold stress period. Therefore, it provides better protection to acclimated cool-season turfgrass plants and reserve energy to counter cold stress-induced damages to cellular structures.

Results of proline content data also support the above findings, and indicate that under acclimated conditions, carbon flux is diverted from the TCA cycle to proline synthesis from glutamate through $\alpha$-ketogluterate. All three turfgrass species showed higher accumulation of proline with reductions in temperature and photoperiod. Amino acids also play a significant role in the cold hardiness of plants. Accumulation of specific amino acids during cold acclimation was observed in several plants (Sagisaka and Araki, 1983; Sakai and Larcher, 1987). The studies conducted on annual bluegrass showed a higher accumulation of amino acids with cold acclimation (Dionne et al., 2001). After subfreezing temperatures, a higher accumulation of proline, glutamine, and glutamic acid in annual bluegrass crown was observed. As a most abundant amino acid, proline plays several crucial roles in plant cells during stress. In stress-induced conditions, the most important function of proline, we suggest, is its active metabolic role, where proline can act as an alternative reducing equivalent instead of NADH to drive mitochondrial oxidative phosphorylation for energy (ATP) synthesis (Shetty, 2004). On the other hand, in the cytosol, during reduction of $\mathrm{P} 5 \mathrm{C}$ to proline, it provides NADP+, which is cofactor for G6PDH (Shetty 2004). As G6PDH catalyzes the first rate-limiting step of the pentose phosphate pathway, the synthesis of proline in the cytosol is directly linked with the regulation of this pathway. Therefore, under stress situations, proline can play dual roles, one in the mitochondria, and another in the cytosol, and thus be able to drive the synthesis of NADPH and sugar phosphates for supporting anabolic pathways, including phenolic synthesis, and antioxidant response pathways (Shetty and Wahlqvist, 2004). During acclimation, proline synthesis in the cytosol and catabolism in the mitochondria allow forward stimulation of the proline-associated pentose phosphate pathway to meet the anabolic demands of NADPH and also provide energy efficiency via proline oxidation, thereby reducing NADH generation by an incomplete turn of the TCA cycle at the level of $\alpha$-ketogluterate. Comparatively lower proline accumulation was observed in acclimated kentucky bluegrass. The activity of PDH in acclimated kentucky bluegrass manifests clearly and this is the likely reason for lower proline content in this species. It indicates a probable proline oxidation in kentucky bluegrass to support mitochondrial oxidative phosphorylation. This suggests a metabolic role for proline in acclimated cool-season turfgrass, which also supports the pentose phosphate pathway due to higher G6PDH activity in acclimated turfgrass plants.

The reaction center of PSII is frequently undergoing photoinduced damage known as photoinhibition. Under stress conditions, photoinhibition is induced by less than optimal electron transfer when the capacity of photochemistry and dissipative mechanisms are exhausted. We measured the maximum quantum efficiency of PSII photochemistry by estimating the $F_{v} / F_{m}$ ratio. Stress can affect $F_{v} / F_{m}$ by enhanced damage of the $D 1$ protein and by reduced activity of the D1 repair system. Our results indicated a reduction of the $\mathrm{F}_{\mathrm{v}} / \mathrm{F}_{\mathrm{m}}$ ratio in acclimated turfgrass plants, and the reduction was increased in the case of perennial ryegrass. As perennial ryegrass is the least coldtolerant species within the three investigated cool-season turfgrass plants, the estimation of photosynthetic activity supports the above rationale.

Another interesting finding of our study was that the biochemical changes of all three cool-season turfgrass species were not similar during acclimation. Although creeping bentgrass is the most cold tolerant cool-season turfgrass in this study, kentucky bluegrass showed the most efficient cold tolerance mechanism during above freezing acclimation period. It is possible that in the case of creeping bentgrass, 
the major adjustment may take place under subfreezing temperatures rather than above freezing acclimation. Our results partially support the above rationale and, in summary, all three cool-season turfgrass species have shown a relationship between redox protections through stimulation of the antioxidant response system with metabolic regulation through the proline-associated pentose phosphate pathway during acclimation. It suggests that during acclimation, a significant adjustment takes place to counter oxidative damage by adapting an energy-efficient response system in cool-season turfgrass. This mechanism may help these cold-adapted species to withstand a severe winter without significant cellular damage. This study can provide clues to understand the possible defense systems of cool-season turfgrass during winter stress. It will also help to develop new strategies to improve cold tolerance behavior in cool-season turfgrass. Further extension of this study with different cultivars or investigation under subfreezing temperatures can provide a detailed picture of stress tolerance mechanisms of cool-season turfgrass.

\section{Literature Cited}

Alberdi, M. and L.J. Corcuera. 1991. Cold acclimation in plants. Phytochemistry 30:3177-3184.

Anderson, J.V., B.I. Chevone, and J.L. Hess. 1992. Seasonal variation in antioxidant system of eastern white pine needles. Plant Physiol. 98:501-508.

Asada, K. 1993. Divergence of peroxide-scavenging peroxidases in organisms, p. 289-298. In: K. Yagi (ed.). Active oxygens, lipid peroxides and antioxidants. CRC Press, Boca Raton, FL.

Beard, J.B. 1973. Turfgrass: Science and culture. Prentice Hall, Englewood Cliffs, NJ.

Beers, R.F. and I.W. Sizer. 1952. A spectrometric method for measuring the break down of the hydrogen peroxide by catalase. J. Biol. Chem. 195:133-140.

Bhowmik, P.C., K. Shetty, and D. Sarkar. 2008. Cold-stress response of cool-season turfgrass: Antioxidant mechanism, p. 507-530. In: Pessarakli, M. (ed.). Handbook of turfgrass management and physiology. CRC Press, Boca Raton, FL.

Bowler, C., W. Van Camp, M. Van Montagu, and D. Inze. 1994. Superoxide dismutase in plants. Crit. Rev. Plant Sci. 13:199-218.

Bradford, M. 1976. A rapid and sensitive method for the quantification of microgram quantities of protein utilizing the principle of proteindye binding. Ann. Biochem. 72:248-254.

Bregman, A.A. 1987. Laboratory investigations in cell biology. Wiley, Hoboken, NJ.

Christ, M., B. Luu, J.E. Mejia, I. Moosbrugger, and P. Bischoff. 1993. Apoptosis induced by oxysterols in murine lyphoma cells and in normal thymocytes. Immunology 78:455-460.

Christie, P.J., M.R. Alfenito, and V. Walbot. 1994. Impact of lowtemperature stress on general phenylpropanoid and anthocyanin pathways: Enhancement of transcript abundance and anthocyanin pigmentation in maize seedlings. Planta 194:541-549.

Costilow, R.N. and D. Cooper. 1978. Identify of proline dehydrogenase and pyrroline-5-carboxylic acid reductase in Clostridium sporogenes. J. Bacteriol. 134:139-146.

Deutsch, J. 1983. Glucose-6-phosphate dehydrogenase, p. 191-197. In: H.V. Bergmeyer, N. Grassl, and H.E. Walter (eds.). Methods of enzymatic analysis. 3rd ed. Verlag Chemie, VCH Publishers, Deerfield Beach, FL.

Dionne, J., Y. Castonguay, P. Nadeau, and Y. Desjardins. 2001. Amino acids and protein changes during cold acclimation of green-type annual bluegrass (Poa annua L.) ecotypes. Crop Sci. 41:18621870 .

Dorffling, K., H. Dorffling, G. Lesselich, E. Luke, C. Zimmerman, G. Melz, and H.U. Jurgens. 1997. Heritable improvement of frost tolerance in winter wheat by in vitro selection of hydroxyprolineresistant proline overproducing mutants. Euphytica 93:1-10.

Feierabend, J., C. Schaan, and B. Hertwig. 1992. Photoinactivation of catalase occurs under both high- and low-temperature stress conditions and accompanies photoinhibition of photosystem II. Plant Physiol. 100:1554-1561.

Fuchs, D., G.B. Bitterlich, I. Wede, and H. Wachter. 1997. Reactive oxygen and apoptosis, p. 139-167. In: J.G. Scandalios (ed.). Oxidative stress and the molecular biology of antioxidant defenses. Cold Spring Harbor Laboratory Press, Cold Spring Harbor, NY.

Hagedorn, C.H. and J.M. Phang. 1983. Transfer of reducing equivalents into mitochondria by the interconversions of proline and pyrroline-5-carboxylate. Arch. Biochem. Biophys. 225:95-101.

Halliwell, B. and J.M.C. Gutteridge. 1989. Free radicals in biology and medicine. 2nd ed. Clarendon Press, Oxford University Press, New York.

Jahnke, L.S., M.R. Hull, and S.P. Long. 1991. Chilling stress and oxygen metabolizing enzymes in Zea mays and Zea diploperennis. Plant Cell Environ. 14:7-104.

Javanmardi, J., C. Stushnoff, E. Locke, and J.M. Vivanco. 2003. Antioxidant activity and total phenolic content of Iranian Ocimum accessions. Food Chem. 83:547-550.

Kendall, E.J. and B.D. McKersie. 1989. Free radical and freezing injury to cell membranes of winter wheat. Physiol. Plant. 76:86-94.

Laloue, H., F. Weber-Lofti, A. Lucau-Danila, and P. Gullemat. 1997. Identification of ascorbate and guaiacol peroxidase in needle chloroplasts of spruce trees. Plant Physiol. Biochem. 35:341-346.

Massacci, A., M.A. Iannelli, F. Pietrini, and F. Loreto. 1995. The effect of growth at low temperature on photosynthetic characteristics and mechanisms of photoprotection of maize leaves. J. Expt. Bot. 46:119-127.

McCue, P. and K. Shetty. 2002. Clonal herbal extracts as elicitors of phenolic synthesis in dark germinated mungbeans for improving nutritional value with implications for food safety. J. Food Biochem. 26:209-232.

McCue, P., Z.X. Zheng, J.L. Pinkham, and K. Shetty. 2000. A model for enhanced pea seedlings vigor following low $\mathrm{pH}$ and salicylic acid treatments. Process Biochem. 35:603-613.

McKersie, B.D., Y. Chen, M. De Beus, S. Bowley, C. Bowler, D. Inzé, K. D'Halluin, and J. Botterman. 1993. Superoxide dismutase enhances tolerance of freezing stress in transgenic alfalfa (Medicago sativa L.). Plant Physiol. 103:1155-1163.

Morales, M. and A.R. Barcello. 1997. A basic peroxidase isoenzyme from vacuoles and cell walls of Vitis vinifera. Phytochemistry 45:229-232.

Oberley, L.W. and D.R. Spitz. 1984. Assay of SOD activity in tumor tissue. Methods Enzymol. 105:457-464.

Paliyath, G. and M.J. Droillard. 1992. The mechanism of membrane deterioration and disassembly during senescence. Plant Physiol. Biochem. 30:789-812.

Pellegrini, N., R. Re, M. Yang, and C. Rice-Evans. 1999. Screening of dietary carotenoids and carotenoid-rich fruit extracts for antioxidant activities applying 2, 2'-azinobis [3-ethylenebenzothiazoline-6-sulfonic acid] radical cation decolorization assay. Methods Enzymol. 299:379-389.

Pennycooke, J.C., S. Cox, and C. Stushnoff. 2005. Relationship of cold acclimation, total phenolic content and antioxidant capacity with chilling tolerance in petunia (Petunia $\times$ hybrida). Environ. Exp. Bot. 53:225-232.

Phang, J.M. 1985. The regulatory functions of proline and pyrroline-5carboxylic acid. Curr. Top. Cell. Regul. 25:91-132.

Pinhero, R.G., M.V. Rao, G. Paliyath, D.P. Murr, and R.A. Fletcher. 1997. Changes in activities of antioxidant enzymes and their relationship to genetic and paclobutrazol-induced chilling tolerance of maize seedlings. Plant Physiol. 114:695-704.

Polle, A. 1997. Defense against photooxidative damage in plants, p. 623-666. In: J.G. Scandalios (ed.). Oxidative stress and the molecular biology of antioxidant defenses. Cold Spring Harbor Laboratory Press, Cold Spring Harbor, NY. 
Prasad, T.K. 1996. Mechanism of chilling induced oxidative stress injury and tolerance in developing maize seedlings: Changes in antioxidant system, oxidation of proteins and lipids and protease activities. Plant J. 10:1017-1026.

Prasad, T.K., M.D. Anderson, B.A. Martin, and C.R. Stewart. 1994. Evidence for chilling-induced oxidative stress in maize seedlings and a regulatory role for hydrogen peroxide. Plant Cell 6:65-74.

Rice-Evans, C.A., N.J. Miller, and G. Paganga. 1997. Antioxidant property of phenolic compounds. Trends Plant Sci. 2:152159.

Sagisaka, S. 1974. Transition of metabolisms in living poplar bark from growing to wintering stages and vice versa. Plant Physiol. 54:544-549.

Sagisaka, S. and T. Araki. 1983. Amino acids pools in perennial plants at the wintering stage and at the beginning of growth. Plant Cell Physiol. 24:479-494.

Sakai, A. and W. Larcher. 1987. Frost survival of plants: Response and adaptation to freezing stress. Springer-Verlag, Berlin.

Schöner, S. and H. Krause. 1990. Protective systems against active oxygen species in spinach: Response to cold acclimation in excess light. Planta 180:383-389.

Shetty, K. 1997. Biotechnology to harness the benefits of dietary phenolics: Focus on Lamiaceae. Asia Pac. J. Clin. Nutr. 6:162-171.
Shetty, K. 2004. Role of proline-linked pentose phosphate pathway in biosynthesis of plant phenolics for functional food and environmental applications: A review. Process Biochem. 39:789-803.

Shetty, K. and M. Wahlqvist. 2004. A model for the role of prolinelinked pentose phosphate pathway in phenolic phytochemical biosynthesis and mechanism of action for human health and environmental applications. Asia Pac. J. Clin. Nutr. 13:1-24.

Shetty, K., O.F. Curtis, R.E. Levin, R. Witkowsky, and W. Ang. 1995. Prevention of virtification associated with in vitro shoot culture of oregano (Origanum vulgare) by Pseudomonas spp. J. Plant Physiol. 147:447-451.

Sobczyk, E.A. and A. Kacperska-Palacz. 1980. Changes in some enzyme activities during cold acclimation of winter rape plants. Acta Physiol. Plant. 2:123-131.

Steponkus, P.L. 1990. Cold acclimation and freezing inzury from a perspective of plasma membrane, p. 1-16. In: F. Katterman (ed.). Environmental injury to plants. Academic Press, San Diego.

Wise, R. and A. Naylor. 1987. Chilling enhanced photooxidation: Evidence for the role of singlet oxygen and superoxide in the breakdown of pigments and endogenous antioxidants. Plant Physiol. 83:278-282. 